$\mathrm{Nr} 8$

WARSZAWA-KRAKÓW 2006

TOMASZ RACHWAE

Akademia Pedagogiczna, Kraków

\title{
Restrukturyzacja technologiczna przedsiębiorstw przemysłowych Polski Południowo-Wschodniej jako czynnik podnoszenia ich konkurencyjności na rynku międzynarodowym
}

Proces restrukturyzacji przemysłu, w tym podstawowych jego elementów, tj. przedsiębiorstw przemysłowych, jest procesem ze swej natury bardzo złożonym. Za Pasiecznym (1997) i Nalepką (1997, 1998) można wyróżnić dwa główne etapy tego procesu. Pierwszy to uchronienie się przed upadkiem (jest to tzw. restrukturyzacja ratunkowa lub naprawcza), natomiast drugi - to w zależności od stopnia zaawansowania zmian - restrukturyzacja rekonwalescencyjna lub rozwojowa. Pierwszy etap obejmuje zmiany formy organizacyjno-prawnej (najczęściej przekształcenie przedsiębiorstwa państwowego w jednoosobową spółkę Skarbu Państwa) i prywatyzację, racjonalizację poziomu zatrudnienia, restrukturyzację finansową (negocjacje z bankami i wierzycielami), rezygnację z produkcji wyrobów, które nie znajdują nabywców na wolnym rynku, oraz pozbywanie się zbędnego majątku produkcyjnego i nieprodukcyjnego. Drugi etap to doskonalenie zasad funkcjonowania, a więc działania na rzecz obniżenia kosztów, budowanie skutecznych strategii finansowych, wprowadzanie nowych produktów i technologii, modernizacja posiadanego majątku produkcyjnego, szerokie i intensywne działania projakościowe, zwiększanie aktywności marketingowej i ekspansja geograficzna oraz wchodzenie w fuzje i przejmowanie innych przedsiębiorstw.

Zasadniczym celem ekonomicznym procesu restrukturyzacji jest poprawa efektywności gospodarowania przedsiębiorstwa w celu osiagnięcia zysku umożliwiającego jego rozwój oraz w dalszej perspektywie zwiększenie konkurencyjności na rynku (Sapijaszka 1997, Pełka 1994). Cel ten jest wręcz niemożliwy do zrealizowanie bez przeprowadzenia głębokich zmian technologicznych w produkcji. Należy więc przyjąć, że czynnikiem warunkującym sukces restrukturyzacji przedsiębiorstwa i osiągnięcia przez niego znaczącej pozycji na rynku międzynarodowym są właśnie zmiany technologiczne, prowadzące do podwyższania stopnia konkurencyjności wyrobów i obniżania kosztów ich wytwarzania. Jak powszechnie wiadomo, po systemie centralnego sterowania większość badanych przedsiębiorstw odziedziczyła mocno zużyty majątek produkcyjny, a produkowane wyroby były opóźnione technologicznie w stosunku do poziomu światowego. Bardzo często stosowane technologie produkcji uniemożliwiały w praktyce produkcję wyrobów, które byłyby konkurencyjne w nowych warunkach gospodarowania (por. Parysek 1992a,b, Stryjakiewicz 1999). Kolejną barierą konkurowania na rynku międzynarodowym był fakt niespełniania przez nich międzynarodowych norm w zakresie jakości produkcji, w szczególności norm amerykańskich i Unii Europejskiej. 
W świetle powyższych przesłanek przedmiotem pracy jest restrukturyzacja technologiczna wybranych przedsiębiorstw przemysłowych Polski Południowo-Wschodniej w latach 1989-2001. W artykule ograniczono się do zaprezentowania wyników badań prowadzonych w przedsiębiorstwach, popartych kilkoma charakterystycznym przykładami.

Badaniami objęto 22 duże przedsiębiorstwa przemysłowe położone w Polsce Południowo-Wschodniej, reprezentujące różne typy wielkości, własności oraz działy produkcji przemysłowej (tab. 1). Spełniają one też różne funkcje w strukturze gospodarczej, przy czym większość $\mathrm{z}$ nich należy do kategorii przedsiębiorstw o funkcjach międzynarodowych bądź krajowych z eksportem na rynki międzynarodowe.

Tabela 1. Przedsiębiorstwa objęte badaniami

\begin{tabular}{|c|c|c|c|c|c|c|}
\hline Lp. & $\begin{array}{c}\text { Nazwa } \\
\text { przedsiębiorstwa } \\
\text { - skrócona nazwa* }\end{array}$ & $\begin{array}{l}\text { Loka- } \\
\text { lizacja }\end{array}$ & $\begin{array}{l}\text { Typ wiel- } \\
\text { kości } * *\end{array}$ & $\begin{array}{l}\text { Typ włas- } \\
\text { ności**** }\end{array}$ & Dział PKD & $\begin{array}{l}\text { Funk- } \\
\text { cja }^{* * * *}\end{array}$ \\
\hline 1 & $\begin{array}{l}\text { Bahlsen Sweet } \\
\text { sp. z o.o. i Lajkonik } \\
\text { Snacks S.A. (Skawiń- } \\
\text { skie Zakłady Koncen- } \\
\text { tratów Spożywczych) } \\
\text { - Skawina }\end{array}$ & Skawina & duże & $\begin{array}{l}\text { prywatne } \\
\text { z KZ }\end{array}$ & $\begin{array}{l}15 \text { - Prod. art. spo- } \\
\text { żywczych i napojów }\end{array}$ & krajowa $(\mathrm{m})$ \\
\hline 2 & $\begin{array}{l}\text { Fabryka Aparatury } \\
\text { Elektromechanicznej } \\
\text { „Fanina” S.A. - Fanina } \\
\end{array}$ & Przemyśl & $\begin{array}{l}\text { duże } \\
\text { (średnie) }\end{array}$ & państwowe & $\begin{array}{l}31 \text { - Prod. maszyn } \\
\text { i aparatury elektrycznej }\end{array}$ & krajowa \\
\hline 3 & $\begin{array}{l}\text { Firma Chemiczna } \\
\text { Dwory S.A. - Dwory }\end{array}$ & Oświęcim & $\begin{array}{l}\text { bardzo } \\
\text { duże } \\
\text { (duże) }\end{array}$ & $\begin{array}{l}\text { prywatne } \\
\text { NFI }\end{array}$ & $\begin{array}{l}24 \text { - Prod. wyrobów } \\
\text { chemicznych }\end{array}$ & krajowa (m) \\
\hline 4 & $\begin{array}{l}\text { Firma Oponiarska } \\
\text { „Dębica” S.A. } \\
\text { - Dębica }\end{array}$ & Dębica & \begin{tabular}{|l} 
bardzo \\
duże \\
(duże)
\end{tabular} & $\begin{array}{l}\text { prywatne } \\
\text { z KZ (GPW) }\end{array}$ & $\begin{array}{l}25 \text { - prod. wyrobów } \\
\text { gumowych i tzw. } \\
\text { sztuczn. }\end{array}$ & $\begin{array}{l}\text { między- } \\
\text { narodowa }\end{array}$ \\
\hline 5 & $\begin{array}{l}\text { Huta im. Tadeusza } \\
\text { Sendzimira S.A. - } \\
\text { HTS }\end{array}$ & Kraków & $\begin{array}{l}\text { bardzo } \\
\text { duże }\end{array}$ & państwowe & 27 - Prod. metali & krajowa (m) \\
\hline 6 & $\begin{array}{l}\text { Huta Stalowa Wola } \\
\text { S.A. - HSW }\end{array}$ & \begin{tabular}{|l} 
Stalowa \\
Wola
\end{tabular} & $\begin{array}{l}\text { bardzo } \\
\text { duże }\end{array}$ & państwowe & $\begin{array}{l}29 \text { - Prod. maszyn } \\
\text { i urządzeń, gdzie in- } \\
\text { dziej nie sklasyfik. }\end{array}$ & $\begin{array}{l}\text { między- } \\
\text { narodowa }\end{array}$ \\
\hline 7 & $\begin{array}{l}\text { Huta Szkła „Jarosław” } \\
\text { S.A. - HSJ }\end{array}$ & Jarosław & duże & $\begin{array}{l}\text { prywatne } \\
\text { z KZ }\end{array}$ & $\begin{array}{l}26 \text { - Prod. wyrobów } \\
\text { z surowców niemetal. i } \\
\text { pozostałych }\end{array}$ & krajowa (m) \\
\hline 8 & $\begin{array}{l}\text { Krakowska Fabryka } \\
\text { Armatur S.A. - KFA }\end{array}$ & Kraków & duże & $\begin{array}{l}\text { prywatne } \\
\text { z inw. finans. }\end{array}$ & $\begin{array}{l}29 \text { - Prod. maszyn } \\
\text { i urządzeń, gdzie in- } \\
\text { dziej nie sklasyfiko- } \\
\text { wana }\end{array}$ & krajowa (m) \\
\hline 9 & $\begin{array}{l}\text { Krakowskie Zakłady } \\
\text { Artykułów Gospodar- } \\
\text { stwa Domowego } \\
\text { „Domgos”- Domgos }\end{array}$ & Kraków & średnie & państwowe & $\begin{array}{l}29 \text { - Prod. maszyn } \\
\text { i urządzeń, gdzie in- } \\
\text { dziej nie sklasyfiko- } \\
\text { wana } \\
\end{array}$ & krajowa \\
\hline 10 & $\begin{array}{l}\text { Krakowskie Zakłady } \\
\text { Elektroniczne „Telpod” } \\
\text { (w upadłości)-Telpod }\end{array}$ & Kraków & $\begin{array}{l}\text { duże } \\
\text { (średnie) }\end{array}$ & państwowe & $\begin{array}{l}32 \text { - Prod. sprzętu } \\
\text { i urządzeń radiowych, } \\
\text { telewiz. i telekom. }\end{array}$ & krajowa (m) \\
\hline
\end{tabular}




\begin{tabular}{|c|c|c|c|c|c|c|}
\hline 11 & \begin{tabular}{|l|} 
Philip Morris Polska \\
S.A. (Zakłady Przemy- \\
słu Tytoniowego \\
w Krakowie) - PMP \\
\end{tabular} & Kraków & duże & $\begin{array}{l}\text { prywatne } \\
\text { z KZ }\end{array}$ & $\begin{array}{l}16 \text { - Prod. wyrobów } \\
\text { tytoniowych }\end{array}$ & krajowa $(\mathrm{m})$ \\
\hline 12 & \begin{tabular}{|l|} 
Fabryka Kosmetyków \\
Miraculum S.A. \\
- Miraculum
\end{tabular} & Kraków & $\begin{array}{l}\text { duże } \\
\text { (średnie) }\end{array}$ & państwowe & $\begin{array}{l}24 \text { - Prod. wyrobów } \\
\text { chemicznych }\end{array}$ & krajowa $(\mathrm{m})$ \\
\hline 13 & $\begin{array}{l}\text { Pliva Kraków S.A. } \\
\text { - Pliva }\end{array}$ & Kraków & duże & $\begin{array}{l}\text { prywatne } \\
\text { z KZ }\end{array}$ & $\begin{array}{l}24 \text { - Prod. wyrobów } \\
\text { chemicznych }\end{array}$ & krajowa $(\mathrm{m})$ \\
\hline 14 & $\begin{array}{l}\text { Przedsiębiorstwo } \\
\text { Odzieżowe „Conres” } \\
\text { S.A. - Conres }\end{array}$ & Rzeszów & duże & $\begin{array}{l}\text { prywatne } \\
\text { NFI }\end{array}$ & $\begin{array}{l}18 \text { - Prod. odzieży } \\
\text { i wyrobów futrzarskich }\end{array}$ & \begin{tabular}{|l|} 
między- \\
narodowa
\end{tabular} \\
\hline 15 & $\begin{array}{l}\text { Tarnobrzeska Fabryka } \\
\text { Obrabiarek „Ponar” } \\
\text { S.A. (w upadłości) } \\
\text { - Ponar } \\
\end{array}$ & $\begin{array}{l}\text { Tarno- } \\
\text { brzeg }\end{array}$ & $\begin{array}{l}\text { duże } \\
\text { (średnie) }\end{array}$ & państwowe & \begin{tabular}{|l}
29 - Prod. maszyn \\
i urządzeń, gdzie in- \\
dziej nie sklasyfiko- \\
wana
\end{tabular} & krajowa \\
\hline 16 & Vistula S.A. - Vistula & Kraków & duże & $\begin{array}{l}\text { prywatne - } \\
\text { rozproszony } \\
\text { akcj. z inw. } \\
\text { finansowym } \\
\text { (GPW) }\end{array}$ & $\begin{array}{l}18 \text { - Prod. odzieży } \\
\text { i wyrobów futrzarskich }\end{array}$ & krajowa (m) \\
\hline 17 & $\begin{array}{l}\text { Zakłady Azotowe } \\
\text { w Tarnowie-Mości- } \\
\text { cach S.A. - Azoty }\end{array}$ & Tarnów & $\begin{array}{l}\text { bardzo } \\
\text { duże } \\
\text { (duże) }\end{array}$ & państwowe & $\begin{array}{l}24 \text { - Prod. wyrobów } \\
\text { chemicznych }\end{array}$ & krajowa $(\mathrm{m})$ \\
\hline 18 & $\begin{array}{l}\text { Zakłady Metalowe } \\
\text { „Nimet” - Nimet }\end{array}$ & Nisko & duże & państwowe & $\begin{array}{l}28 \text { - Prod. metalowych } \\
\text { wyrobów gotowych z } \\
\text { wyj. maszyn } \\
\text { i urządzeń }\end{array}$ & $\begin{array}{l}\text { ponad- } \\
\text { regionalna }\end{array}$ \\
\hline 19 & $\begin{array}{l}\text { Zakłady Mięsne } \\
\text { „Nisko” S.A. (w upa- } \\
\text { dłości) - Nisko }\end{array}$ & Nisko & duże & \begin{tabular}{|l} 
prywatne \\
Z inwestorem \\
strategicz- \\
nym \\
\end{tabular} & $\begin{array}{l}15 \text { - Prod. art. spo- } \\
\text { żywczych i napojów }\end{array}$ & $\begin{array}{l}\text { ponad- } \\
\text { regionalna }\end{array}$ \\
\hline 20 & $\begin{array}{l}\text { Zakłady Płyt Pilśnio- } \\
\text { wych S.A. - ZPP }\end{array}$ & Przemyśl & duże & $\begin{array}{l}\text { prywatne } \\
\text { NFI }\end{array}$ & $\begin{array}{l}\text { 20. - Prod. drewna } \\
\text { i wyrobów z drewna }\end{array}$ & $\begin{array}{l}\text { ponad- } \\
\text { regionalna }\end{array}$ \\
\hline 21 & $\begin{array}{l}\text { Zakłady Przemysłu } \\
\text { Cukierniczego „San” } \\
\text { S.A. - San }\end{array}$ & Jarosław & duże & $\begin{array}{l}\text { prywatne } \\
\text { z KZ }\end{array}$ & $\begin{array}{l}15 \text { - Prod. art. spo- } \\
\text { żywczych i napojów }\end{array}$ & krajowa $(\mathrm{m})$ \\
\hline 22 & $\begin{array}{l}\text { Zakłady Przemysłu } \\
\text { Cukierniczego „Wa- } \\
\text { wel” S.A. - Wawel }\end{array}$ & Kraków & duże & \begin{tabular}{|l} 
prywatne-- \\
akcjonariat \\
pracowniczy \\
(GPW) \\
\end{tabular} & $\begin{array}{l}15 \text { - Prod. art. spo- } \\
\text { żywczych i napojów }\end{array}$ & krajowa $(\mathrm{m})$ \\
\hline
\end{tabular}

* ze względu na przejrzystość tekstu nazwa ta jest używana w dalszej części pracy

**ze względu na przyjęty cel pracy przynależność wielkościową określono wg stanu zatrudnienia na początku badanego okresu (50-250 średnie, 250-3000 duże, pow. 3000 bardzo duże), w nawiasach podano przynależność wg stanu zatrudnienia na końcu okresu.

*** oznaczenie typu własności: „państwowe” - przedsiębiorstwa państwowe, JSSP oraz przedsiębiorstwa z większościowym udziałem SP, prywatne z KZ - prywatne z dominującym udziałem kapitału zagranicznego (inwestora branżowego), prywatne NFI - należące do NFI, GPW - spółka notowane na Giełdzie Papierów Wartościowych, dane na koniec okresu badawczego lub wg przeważającego typu własności w całym okresie badań ****krajowa $(\mathrm{m})$ - przedsiębiorstwa o funkcjach krajowych, eksportujące część produkcji na rynki międzynarodowe

Źródło: opracowanie własne 
W wyniku przeprowadzonych badań w grupie badanych przedsiębiorstw wyodrębniono 4 kategorie przedsiębiorstw wg kryterium zaawansowania zmian w technologii produkcji, przeprowadzonych w przyjętym okresie badawczym:

1. przedsiębiorstwa o bardzo dużych zmianach technologicznych - wprowadziły zupełnie nową technologię do całości produkcji lub wprowadziły nową technologię do części wydziałów produkcyjnych, znacznie modernizując pozostałe linie technologiczne;

2. przedsiębiorstwa o dużych zmianach technologicznych - wprowadziły nową technologię do części produkcji, nie modernizując znacząco pozostałych linii produkcyjnych lub znacznie zmodernizowały wszystkie linie produkcyjne; do grupy tej zaliczono także przedsiębiorstwa, które wprowadziły nową technologię produkcji (w porównaniu z dotychczas stosowaną w Polsce), ale była to technologia używana i wycofywana z innych wiodących zakładów na świecie;

3. przedsiębiorstwa o niewielkich zmianach technologicznych - poprzestały na częściowej modernizacji linii produkcyjnych, a wprowadzenie nowych technologii ograniczone było jedynie do pobocznych, a nie podstawowych procesów produkcyjnych (np. pakowanie);

4. przedsiębiorstwa bez zmian technologicznych - nie wprowadziły zmian w technologii produkcji, ograniczając się jedynie do bieżącej konserwacji i napraw używanych urządzeń lub wymiany części urządzeń pomocniczych.

Należy zwrócić uwagę, że komputeryzację procesów zarządzania (tj. wyposażenie działów administracyjnych w komputery) uznano jako standard zmian technicznych wprowadzany we wszystkich przedsiębiorstwach (także tych, w których nie wprowadzono żadnych innowacji technologicznych). Fakt ten nie miał więc wpływu na zakwalifikowanie przedsiębiorstwa do wyższej kategorii. Jednak wprowadzenie komputerowego sterowania procesem produkcji lub fazy projektowania i wdrażania do produkcji nowych wyrobów uznano za istotną innowację w technologii produkcji. Okazało się jednak, że wprowadzenie komputerowego sterowania procesem produkcji jest nierozerwalnie związane $\mathrm{z}$ wprowadzeniem nowych linii technologicznych.

Tabela 2. Zestawienie badanych przedsiębiorstw wg stopnia zawansowania przeprowadzonych zmian technologicznych

\begin{tabular}{|l|l|l|}
\hline \multicolumn{1}{|c|}{ Kategoria przedsiębiorstw } & Liczba przedsięb. & \multicolumn{1}{c|}{ Wyszczególnienie } \\
\hline bardzo duże zmiany techn. (BD) & 4 & Dębica, HSJ, Pliva, PMP \\
\hline duże zmiany techn. (D) & 11 & $\begin{array}{l}\text { Azoty, Conres, Dwory, HTS, KFA, } \\
\text { Miraculum, San, Skawina, Vistula, } \\
\text { Wawel, ZPP }\end{array}$ \\
\hline niewielkie zmiany techn. (N) & 4 & Domgos, Fanina, HSW, Nisko \\
\hline brak zmian techn. (BZ) & 3 & Nimet, Ponar, Telpod \\
\hline
\end{tabular}

Źródło: opracowanie własne

Do grupy pierwszej zaliczono 4 przedsiębiorstwa. Są to duże i bardzo duże przedsiębiorstwa przejęte przez inwestorów zagranicznych. Dokonano w nich całkowitej wymiany głównych linii technologicznych.

Typowym przykładem z tej grupy przedsiębiorstw jest Huta Szkła Jarosław. Do 1997 r., tj. w ciągu 4 lat po przejęciu przedsiębiorstwa przez koncern Owens-Illinois(USA), wymienione zostały dwie z czterech pracujących wanien szklarskich. Nowe wanny są całkowicie zautomatyzowane. Proces produkcji jest kontrolowany za pomocą komputera, sprawdzającego ponad 200 parametrów procesu wytopu szkła. Dodatkowo w wannach zamontowano specjalistyczne kamery, wytrzymałe na wysokie temperatury, umożliwiające podgląd procesu wytopu. Program 
sterowania procesem produkcji może być zdalnie modyfikowany, dzięki połączeniu modemem z Centrum Technologicznym koncernu w Toledo (Ohio, USA). W ramach modernizacji zwiększono wydajność wanien o ok. 36\% (z 220 do 300 ton szkła na dobę) przy jednoczesnym obniżeniu zużycia energii o 27\% (z 1500 do $1100 \mathrm{kcal} / \mathrm{kg}$ szkła). Nowa technologia spowodowała zmniejszenie o ok. $60 \%$ emisji szkodliwych substancji (głównie tlenków azotu) do atmosfery. Zainstalowano także nowoczesne automaty do formowania, przystosowane do produkcji wyrobów cienkościennych (bardzo lekkich) i zarazem bardziej wytrzymałych metodą nnpb (narrow neck press \& blow). Jako pierwsza w Polsce huta wprowadziła taką rewolucję technologiczną. Obecnie każda huta, która chce liczyć się na rynku opakowań szklanych, produkuje takie opakowania. Pozwoliło to na zmniejszenie wagi butelek o blisko połowę (np. cienkościenna butelka do piwa waży $136 \mathrm{~g}$, a tradycyjna ok. $285 \mathrm{~g}$ ). Wpłynęło to znacznie na zwiększenie zainteresowania nimi producentów różnego typu napojów, w tym także tych, którzy tradycyjnie pakowali swoje produkty do butelek plastikowych PET lub kartonów (Rachwał 2000b). W kolejnych latach przedsiębiorstwo zainstalowało trzecią i zmodernizowało czwartą wannę szklarską oraz zainstalowało nowe automaty do formowania. W 2002 r. posiadało 14 takich urządzeń formujących, przystosowanych do produkcji wyrobów cienkościennych. Zainstalowano także nowe linie kontrolne oraz urządzenia tzw. zimnego końca, tj. odprężarki oraz urządzenia do automatycznego formowania palet $\mathrm{z}$ wyrobami. Działania te pozwoliły na dalsze zwiększenie wydajności HSJ o ok. 30\% i dwukrotny wzrost produkcji od momentu prywatyzacji. Z myślą o zadowoleniu klientów, którzy coraz częściej zamawiają opakowania o indywidualnym kształcie, dział projektowania form i opakowań wyposażono w specjalistyczny sprzęt komputerowy wraz z oprogramowaniem, umożliwiający szybkie przetwarzanie projektu formy graficznej opakowania szklanego w projekt techniczno-technologiczny. Za pomocą symulacji komputerowej projektant może jeszcze w fazie projektowania pokazać klientowi, jak będzie wyglądać zamawiane przez niego opakowanie. Efektem tych inwestycji jest udział rynkowy huty w Polsce szacowany na ponad $40 \%$ oraz wzrost eksportu do $20 \%$. Stosowana technologia należy do jednej z najbardziej zaawansowanych w Europie, dlatego przedsiębiorstwo pod względem jakości produkcji nie będzie miało żadnych problemów ze sprzedażą swoich produktów na jednolitym rynku Unii Europejskiej. Wysoka jakość produkcji uzyskana, m.in. dzięki nowym inwestycjom, została potwierdzona otrzymaniem przez hutę już w 1997 r. certyfikatu zarządzania jakością ISO9001. Od momentu prywatyzacji koncern zainwestował w hutę blisko $100 \mathrm{mln}$ USD (ponad 3-krotnie przekraczając zobowiązania inwestycyjne). Wysoki poziom inwestycji znajduje odbicie w wartości majątku trwałego - jego wartość w cenach bieżących wzrosła z 28,8 mln zł w 1993 r. (tj. roku przejęcia przez inwestora) do 259,8 mln na koniec $2001 \mathrm{r}$., tj. ponad 9-krotnie (wzrost do 902\%). Należy podkreślić, że w strukturze majątku trwałego pod względem wartości największy udział mają urządzenia techniczne i maszyny, które w 2001 r. miały wartość 174,2 mln zł, co stanowi $67 \%$ wartości majątku trwałego. Poziom inwestycji obrazuje również ponad 4krotny wzrost kosztów amortyzacji z 7,98 mln zł w 1993 r. do 56,31 mln zł w 2001 r., tj. do $706 \%$.

Dobrym przykładem bardzo dużego zaangażowania inwestycyjnego w technologię produkcji jest także Pliva. Chociaż chorwacki koncern nie należy do światowych liderów przemysłu farmaceutycznego i sam musiał przeprowadzić w latach 90. kosztowną restrukturyzację zakładów produkcyjnych we własnym kraju, inwestycję w krakowską Polfę potraktował bardzo poważnie, co pozwala na przypuszczenie, że wyznaczył jej jedną ze strategicznych ról w strukturze koncernu. W 1998 r., niecałe 2 lata po przejęciu przedsiębiorstwa przez inwestora, oddano do użytku obiekt Form Suchych II, jeden z najnowocześniejszych wydziałów produkcyjnych w Europie. Koszt tej inwestycji wyniósł ok. $50 \mathrm{mln}$ zł. Linie produkcyjne spełniają najwyższe europejskie wymagania jakościowe GMP i amerykańskie FDA. Powierzchnia wy- 
działu wynosi 7 tys. $\mathrm{m}^{2}$. Produkcja rozmieszczona jest na 5 kondygnacjach, dlatego budynek wyposażono w specjalne windy do transportu surowców, półproduktów i towarów. W projekcie obiektu wykorzystano powszechnie najbardziej dogodny i tani grawitacyjny sposób transportu, wyeliminowano także niepotrzebne krzyżówki dróg transportowych. Większość procesów odbywa się w warunkach hermetycznych. Zdolność produkcyjna nowego wydziału to ok. 1,5 mld sztuk tabletek, drażetek bądź kapsułek w ciągu roku. W 1999 r. wydział ten wyposażono w nową, całkowicie zautomatyzowaną linię pakującą. Do listy inwestycji Plivy należy zaliczyć także park laboratoryjny, dział ampułkarni, magazyn wyrobów gotowych, nowy biurowiec firmy (za $6 \mathrm{mln}$ dol.) oraz nową infrastrukturę informatyczną łączącą wszystkie działy firmy. Kontynuowane były inwestycje w czystość produkcji. Już w 1994 r. przedsiębiorstwo zostało skreślone z listy 80. zakładów o największej uciążliwości dla środowiska. Kolejne proekologiczne inwestycje koncernu pozwoliły Plivie na poddaniu się specjalnemu audytowi weryfikującemu Czystszą Produkcję. Decyzją Kapituły Polskiego Rejestru Czystszej Produkcji i Odpowiedzialnej Przedsiębiorczości została wpisana do tego elitarnego rejestru i otrzymała dyplom uznania za wprowadzenie Czystszej Produkcji jako Systemu Zarządzania Środowiskiem. W efekcie tych działań firma może się legitymować także międzynarodowym certyfikatem zarządzania środowiskiem ISO14001. W wyniku restrukturyzacji grupy Pliva na świecie planuje się kolejne inwestycje w krakowskim zakładzie (o wartości $25 \mathrm{mln}$ USD, łączna wartość planowanych inwestycji do końca 2005 ma wynieść 77 mln USD). Do Krakowa zostanie przeniesiona część produkcji z zakładu AWD w Dreźnie, a także z zakładów w Chorwacji. Nowa linia produkcyjna (zakład form musujących) została wybudowana w latach 2003-2004 r. Poza tym w Krakowie ma powstać międzynarodowe centrum dystrybucyjne leków odpowiadające za sprzedaż leków całej grupy Pliva w naszej części Europy. Efekt przeprowadzonych

w latach 1998-2001 inwestycji obrazuje zmiana wartości składników rzeczowego majątku trwałego Plivy (tab. 3).

Tabela 3. Zmiany wartości składników rzeczowego majątku trwałego w Plivie w 1. 1997-2001

\begin{tabular}{|c|c|c|c|c|c|}
\hline \multirow{2}{*}{ Wyszczególnienie } & \multicolumn{2}{|c|}{$\begin{array}{c}\text { stan na koniec } \\
1997 \mathrm{r} .\end{array}$} & \multicolumn{2}{|c|}{$\begin{array}{l}\text { stan koniec } \\
2001 \mathrm{r} \text {. }\end{array}$} & \multirow{2}{*}{$\begin{array}{c}\text { dynamika } \\
(1997=100 \\
)\end{array}$} \\
\hline & mln zł & $\%$ & $\operatorname{mln} \mathrm{zł}$ & $\%$ & \\
\hline $\begin{array}{l}\text { MAJĄTEK TRWAEY } \\
\text { ogółem }\end{array}$ & 91880,1 & 100,0 & 348792,7 & 100,0 & 379,6 \\
\hline $\begin{array}{l}\text { Rzeczowy majątek trwały, } \\
\text { w tym: }\end{array}$ & 90456,9 & 98,5 & 327854,7 & 94,0 & 362,4 \\
\hline Grunty własne & 0,0 & 0,0 & 4292,3 & 1,2 & - \\
\hline Budynki i budowle & 19605,0 & 21,3 & 179659,7 & 51,5 & 916,4 \\
\hline $\begin{array}{l}\text { Urządzenia techniczne } \\
\text { i maszyny }\end{array}$ & 16661,3 & 18,1 & 117248,3 & 33,6 & 703,7 \\
\hline Środki transportu & 1106,9 & 1,2 & 6482,8 & 1,9 & 585,7 \\
\hline Pozostałe środki trwałe & 1822,9 & 2,0 & 6815,2 & 2,0 & 373,9 \\
\hline Inwestycje rozpoczęte & 51069,1 & 55,6 & 12578,9 & 3,6 & 24,6 \\
\hline zaliczki na poczet inwestycji & 191,7 & 0,2 & 777,5 & 0,2 & 405,6 \\
\hline
\end{tabular}

Źródło: opracowanie własne na podstawie danych Plivy

Jak wskazuje obliczony wskaźnik dynamiki, w przyjętym przekroju czasowym wartość w cenach bieżących budynków i budowli w Plivie wzrosła ponad 9-krotnie (do 916,4\%), 
a urządzeń technicznych i maszyn ponad 7-krotnie (do 703,7\%). Blisko 6-krotny wzrost wartości (do 585,7\%) nastąił w środkach transportu i prawie 4-krotny w pozostałych środkach trwałych (do 373,9\%). Udział budynków i budowli oraz urządzeń technicznych i maszyn w ogólnej wartości majątku trwałego przekroczył 85\% w 2001 r. O wysokim poziomie inwestycji świadczy także wzrost kosztów amortyzacji z 6,2 mln zł w 1997 r. do 43,4 mln zł w 2001 r., tj. do $700 \%$.

Największa liczba przedsiębiorstw (11) należy do drugiej grupy przedsiębiorstw o dużych zmianach technologicznych. Typowym jej przedstawicielem jest Firma Chemiczna „Dwory” S.A. w Oświęcimiu, która sukcesywnie modernizuje i wymienia swoje linie technologiczne. W pierwszej połowie lat 90 . przychody i wypracowywane zyski nie pozwalały na szerokie działania inwestycyjne, w związku z tym firma skupiła się na pilnych inwestycjach w ochronę środowiska (przedsiębiorstwo należało bowiem do listy 80 największych trucicieli w Polsce ${ }^{*}$. Działania inwestycyjne na szeroką skalę prowadzono w 1. 1996-1999. Oddano w tym czasie do użytku nowe instalacje produkcyjne styrenu i polistyrenu do spieniania oraz polistyrenu blokowego oraz sukcesywnie unowocześniano pozostałe linie produkcyjne. Łączny koszt inwestycji wyniósł $460 \mathrm{mln}$ zł. Na uwagę zasługuje fakt, że inwestycje realizowane były wyłącznie własnymi środkami i kredytami, przedsiębiorstwo nie ma bowiem silnego inwestora branżowego, natomiast główni właściciele (NFI i Skarb Państwa) nie decydowali się na podniesienie jego kapitału. Konsekwencją poniesionych wydatków był znaczny wzrost zadłużenia firmy, które pod koniec 1999 r. osiągnęło sumę 390 mln zł. Rezultatem realizowanego cyklu inwestycyjnego było zwiększenie skali i unowocześnienie produkcji, poprawa jakości, zmniejszenie kosztów i presji wywieranej na środowisko, co zostało potwierdzone certyfikatami zarządzania jakością ISO9001-2 i zarządzania środowiskiem ISO14001. Firma wprowadziła też zasady zmierzające do wprowadzenia Kompleksowego Systemu Zarządzania Jakością - TQM. W kolejnych latach 2000-2002 kontynuowała działania modernizacyjne. $\mathrm{Na}$ lata 2003-2007 zaplanowano generalne modernizacje i budowę nowych linii produkcyjnych kauczuków i lateksów, które obok polistyrenu należą do strategicznych dziedzin produkcji - Dwory planują wydać na ten cel łącznie $400 \mathrm{mln}$ zł. Jest to jednak zbyt duże obciążenie finansowe dla firmy, dlatego prowadzone sa rozmowy z potencjalnymi inwestorami, głównie z branży przemysłu motoryzacyjnego (m.in. Stomilem Olsztyn i Firmą Oponiarską „Dębica”), gdyż przedsiębiorstwa te byłyby największymi odbiorcami wyrobów wytwarzanych na nowych liniach produkcyjnych.

Interesującym przykładem są Zakłady Przemysłu Cukierniczego „San”. Wymianę swoich linii technologicznych firma zaczęła już w połowie lat 90., wkrótce po przejęciu przez inwestora zagranicznego, koncern United Biscuits, który wydał na modernizację Sanu blisko 20 mln funtów, wypełniając zobowiązania inwestycyjne z umowy prywatyzacyjnej. Dzięki temu firma stała się pod koniec lat 90. czołowym producentem ciastek w Polsce, z udziałem w rynku szacowanym na $20 \%$. Do połowy 1998 r. wymieniono dwie z czterech linii produkcyjnych, urządzenia do produkcji zostały najprawdopodobniej przeniesione z fabryki niemieckiej, gdzie zostały zastąpione maszynami o wyższym stopniu zaawansowania technologicznego. Można więc sądzić, że inwestycja ta byłą formą przemieszczania urządzeń produkcyjnych $\mathrm{z}$ wiodących firm zlokalizowanych na terenie UE do Jarosławia (Rachwał 2000a). W latach 1999-2000 zmodernizowano pozostałe linie produkcyjne oraz zakupiono szereg drobnych urządzeń wspomagających, jak urządzenia znakujące kartony, wagi kontrolne, wózki do ciast, rozkładacze ciastek, stoły do pakowania, wydłużenie tunelu chłod-

\footnotetext{
* Decyzją głównego inspektora ochrony środowiska firma została skreślona z tej listy w 2002 r.
} 
niczego w linii oblewania czekoladą, klimatyzacja do magazynu wyrobów gotowych. Inwestycje te pozwoliły na wzrost produkcji z 13 tys. ton w 1996 r. do 16 tys. ton 1998 r., jednak nie spowodowały osiagnięcia takiej przewagi konkurencyjnej, która pozwoliłaby na zahamowanie spadku sprzedaży po 1998 r. do 10 tys. ton w 2001 r. i ok. 8 tys. ton w 2002. W utracie dotychczasowej pozycji konkurencyjnej nie pomogła przedsiębiorstwu także znaczna redukcja zatrudnienia (z 940 osób w 1998 r. do 670 w 2001 r.), którą umożliwiło zakończenie okresu gwarancji zatrudnienia w 1998 r. Działalność inwestycyjna na szerszą skalę została w 2000 r. w przedsiębiorstwie wstrzymana, gdyż prowadzone były negocjacje w sprawie sprzedaży przedsiębiorstwa.

Nowym właścicielem Sanu została firma Lu Polska, należąca do koncernu Danone (który jeszcze w 1994 r. chciał kupić przedsiębiorstwo, jego oferta przegrała jednak z ofertą United Biscuits). Przejęcie Sanu przez Danone było formalnością, gdyż koncern ten utworzył wcześniej międzynarodową spółkę Final Realm (współudziałowcem był światowy konkurent - koncern Nabisco) i przejął większościowy pakiet udziałów w koncernie United Biscuits, dzieląc się $\mathrm{z}$ Nabisco strefami wpływów w Europie. W wyniku podziału rynku (i tym samym zakładów United Biscuits) koncernowi Danone przypadł właśnie w udziale jarosławski San. Po zmianie właściciela w firmie nie nastąpiły znaczące inwestycje w technologię produkcji, chociaż przedsiębiorstwo zaczęło przynosić w 2002 r. zyski. Niejasne są zamiary koncernu wobec Sanu. W mediach pojawiły się informacje o projekcie zamknięcia firmy (na początku 2003 r. odbywały się protesty załogi w tej sprawie, specjalną sesję zorganizowały też władze miejskie Jarosławia). Być może przejęcie miało na celu eliminację konkurenta $\mathrm{W} \mathrm{z}$ rynku. Oficjalnie koncern potwierdził jedynie zamiar połączenia Sanu z zakładami w Płońsku oraz reorganizację struktury koncernu, polegającej m.in. na zamknięciu 10 fabryk ciastek w Europie (produkcja ciastek należy bowiem do najmniej dochodowych). Można by przypuszczać, że poziom technologiczny Sanu (mimo inwestycji United Biscuits) jest dla nowego właściciela zbyt niski, aby opłacało się nadal inwestować w to przedsiębiorstwo, co może doprowadzić do jego likwidacji. Zainteresowana obroną miejsc pracy załoga złożyła propozycję odkupienia majątku od inwestora i kontynuowania produkcji. Okazuje się jednak, że nowy właściciel chce przenieść linie technologiczne do Płońska. Powstaje więc pytanie, czy rzeczywiście linie te są potrzebne do zwiększenia produkcji w Płońsku, czy po prostu inwestor nie chce dopuścić do kontynuowania produkcji w Jarosławiu przez spółkę pracowniczą, czyli utrzymania konkurencji (wg informacji z początku 2004 r. zakład ma przejąć inny inwestor, Lu Polska nie wyraziło zgody na sprzedaż przedsiębiorstwa spółce pracowniczej).

Do trzeciej, grupy przedsiębiorstw o niewielkich zmianach technologicznych, zaliczono 4 przedsiębiorstwa. Ciekawym przykładem są Zakłady Mięsne „Nisko”. Przeprowadzona na niewielką skalę w poł. lat 90. modernizacja parku maszynowego (pochodzącego jeszcze z lat 70.) oraz instalacja nowych maszyn w oddziale suszarni oraz mechanicznych skórowaczek pozwoliły na utrzymanie dosyć wysokiej jakości produkcji praw eksportowych do krajów Unii Europejskiej i USA. Wartość tych inwestycji szacowana była na $20 \mathrm{mln}$ zł. Brak środków finansowych na dalsze inwestycje (największym właścicielem był NFI Progres, który nie przeznaczał środków na inwestycje) spowodował dalszą dekapitalizację majątku trwałego i w efekcie utratę praw eksportowych. Utworzono jedynie mokrą peklownię i magazyn odpadów poprodukcyjnych oraz wybudowano nowe rampy załadunkowe i wyładunkowe. Sytuacja pogorszyła się jeszcze bardziej pod koniec lat 90. Zakupiono co prawda w 1999 r. 2 nowoczesne masarnice o pojemności 1,5 t, ale na tym inwestycje w technologię produkcji zakończyły się, gdyż nowy właściciel (firma Kera Trading) nie spełnił zobowiązań inwestycyjnych (szacowanych na $28 \mathrm{mln}$ zł). Przedsiębiorstwo utraciło więc prawa eksporto- 
we na wymagające rynki UE i USA, co w powiązaniu ze spadkiem popytu na rynku krajowym oraz celowymi działaniami inwestora na szkodę firmy doprowadziło do jej upadku (Rachwał 2001a). Właściciel firmy Kera Trading (inwestor) i jego pełnomocnicy zostali oskarżeni o celowe działanie na szkodę przedsiębiorstwa i wyprowadzanie jego majątku. Właściciel jest również oskarżany o malwersacje finansowe (m.in. wyłudzenie kredytów w banku w Stalowej Woli na zakup akcji Niska). Powstaje więc pytanie, dlaczego akcjonariusze firmy - Skarb Państwa i NFI (także kontrolowane przez Skarb Państwa) sprzedały większościowy pakiet akcji niesprawdzonemu inwestorowi. Odpowiedź na to pytanie będzie zapewne możliwa dopiero po zakończeniu postępowania sądowego w tej sprawie.

Brak środków finansowych nie pozwalał także pozostałym firmom z tej grupy na duże modernizacje technologii produkcji. Stosunkowo niewielkie przedsiębiorstwa (Domgos, Fanina) nie mogły znaleźć poważnego inwestora, gdyż ze względu na skalę produkcji (i przychodów) nie wzbudzały zainteresowania wśród potencjalnych inwestorów. Przedsiębiorstwa te starały się wygospodarować własne środki na bieżące modernizacje. Problem ze znalezieniem inwestora finansującego zmiany technologiczne miała także HSW. W tym wypadku przeszkodą był zbyt duży rozmiar przedsiębiorstwa. Huta w latach 90. dokonała modernizacji, co pozwoliło jej na utrzymanie się na rynku. Prowadziło to jednak do systematycznego wzrostu zadłużenia i wywierania nacisków na rząd i wierzycieli na ich umorzenie (bądź konwersje wierzytelności na akcje firmy). Dzięki głębokim zmianom organizacyjnym, prowadzącym do podziału firmy na mniejsze spółki, istnieje możliwość znalezienia inwestora dla poszczególnych wydziałów (obecnie w formie spółek). W 2003 r. pojawiła się szansa na inwestycje firm amerykańskich w związku z tzw. zobowiązaniami offsetowymi rządu amerykańskiego. Dla części z nich, jak np. Zakładu Metalurgicznego, ze względu na sytuację rynkową (zbyt wysoka podaż wyrobów hutniczych i ograniczenia w jej produkcji związane $\mathrm{z}$ akcesją Polski do UE) może to jednak okazać się niemożliwe.

Do grupy przedsiębiorstw, które nie dokonały zmian w technologii produkcji, zaliczono Nimet, Telpod, Ponar. W przypadku Nimetu okazało się, że właściciel (Ursus), mający sam ogromne kłopoty finansowe ze swoim wiodącym zakładem w Ursusie, nie był zainteresowany ratowaniem zadłużonych filii. Po usamodzielnieniu się przedsiębiorstwa okazało się, że produkcja na całkowicie przestarzałym parku maszynowym (w dodatku przystosowanym do bardzo specyficznych zamówień głównego odbiorcy) nie pozwala na osiąganie zysków i brak chętnych na przejęcie zakładu w takim stanie. Firma starała się pozyskać kredyt na inwestycje, ale banki odmówiły finansowania, ze względu na zbyt duże ryzyko przedsięwzięcia. Doprowadziło do upadłości firmy. Ta sama przeszkoda - brak środków finansowych - nie pozwoliła na praktycznie żadne inwestycje w 2 pozostałych zakładach z tej grupy. Należy jednak podkreślić, że w przypadku Telpodu sytuacja jest nieco bardzie złożona. Wynika to z faktu, że niemal identyczne trudności w latach transformacji ustrojowej przeżywały prawie wszystkie pozostałe przedsiębiorstwa przemysłu elektronicznego. Jak wskazują moje wcześniejsze badania nad przemysłem elektronicznym w Polsce (Rachwał 2001b), w latach 1989-1998 spadek potencjału produkcyjnego mierzonego liczbą zatrudnionych w przedsiębiorstwach tej branży był znaczny i sięgał aż $76 \%$ (średnia dla 16 wiodących przedsiębiorstw branży), przy czym w trzech przedsiębiorstwach (Diora, Unimor, Zatra) wynosił ponad $90 \%$. Stosunkowo dobrze radziły sobie w nowych warunkach tylko przedsiębiorstwa produkujące wyroby finalne powszechnego użytku, w których zainwestował kapitał zagraniczny (np. Thomson-Polkolor), chociaż przypadek Tonsilu wskazuje, że nawet wejście silnego branżowego inwestora zagranicznego nie gwarantuje powodzenia restrukturyzacji. Przedsiębiorstwa przemysłu elektronicznego, w tym Telpod, oczekiwały więc w latach 
90. na specjalny program inwestycyjny rządu w odniesieniu do tego przemysłu. Zostawienie przedsiębiorstw tej branży własnemu losowi, doprowadziło do w latach 1989-1998 w przemyśle krajowym do drastycznego spadku produkcji podzespołów elektronicznych (np. rezystorów stałych i kondensatorów o ponad 97\% oraz przyrządów półprzewodnikowych o ponad 99\%), a także spadku produkcji wyrobów elektronicznych powszechnego użytku (np. magnetofonów i odbiorników radiofonicznych z zestawami o ok. 95\%, aparatów telefonicznych o prawie 70\%, wyjątek stanowią jedynie składane z importowanych podzespołów telewizory), co oznacza zupełne zniknięcie Polski z grupy liczących się w świecie producentów. W efekcie, znaczenie przemysłu elektronicznego, który powinien być motorem rozwoju gospodarczego Polski i znacząco wpływać na konkurencyjność polskiego przemysłu na rynku międzynarodowym, w tym Unii Europejskiej, stało się marginalne.

Upadek przedsiębiorstw wysokiej techniki przy jednoczesnym pozostawieniu (dzięki administracyjnemu dofinansowaniu ich działalności z przyczyn politycznych czy społecznych ze środków budżetowych), przedsiębiorstw reprezentujących przemysły surowcowe, kapitałochłonne i energochłonne powoduje uwstecznienie struktury wytwórczej przemysłu. Wydaje się więc, że strategicznym błędem było nieprzygotowanie i niewdrożenie specjalnego rządowego programu restrukturyzacji przemysłu elektronicznego wraz z zapewnieniem odpowiednich środków finansowych na jego realizację (tym bardziej, że duże środki finansowe z powodów nacisków społecznych przeznaczane są na przemysły, których znaczenie w gospodarce światowej maleje, takie jak górnictwo czy hutnictwo stali). Ewentualne wdrożenie takiego programu w przyszłości nie uratuje już badanego przedsiębiorstwa Telpod. Okazało się, że po ogłoszeniu upadłości nie ma chętnego kupca na majątek produkcyjny firmy, którego zużycie w 1999 r. szacowane było na 96\% i tym samym nie ma już perspektyw na wznowienie produkcji na bazie Telpodu.

Analizując zmiany technologiczne w przedsiębiorstwach, postawiono pytanie, jakie zachodzą relacje między stopniem zaawansowania zmian technologicznych a cechami przedsiębiorstw, to jest ich strukturą własnościową, wielkością, funkcją, położeniem i przynależnością działową (tab. 4).

Analiza powiązań wskazuje, że grupa przedsiębiorstw o bardzo dużym stopniu zaawansowania zmian technologicznych reprezentowana jest jedynie przez przedsiębiorstwa prywatne $\mathrm{z}$ kapitałem zagranicznych. Jednocześnie należy zwrócić uwagę, że wszystkie 3 przedsiębiorstwa, które nie wprowadziły zmian technologicznych, pozostawały w badanym okresie w rękach państwowych. W grupie 4 przedsiębiorstw o niewielkich inwestycjach technologicznych 3 reprezentują również sektor państwowy. Charakterystyczny jest również fakt, że przedsiębiorstwa z dużym stopniem zaawansowania zmian technologicznych należą głównie do grupy przedsiębiorstw dużych i bardzo dużych pełniących funkcje krajowe $\mathrm{z}$ eksportem na rynki międzynarodowe. Do grup przedsiębiorstw o niewielkich zmianach i braku zmian technologicznych zaliczają się w większości przedsiębiorstwa o funkcjach krajowych i ponadregionalnych. Natomiast do przedsiębiorstw o dużych i bardzo dużych zmianach technologicznych zaliczono głównie przedsiębiorstwa spełniające funkcje międzynarodowe i krajowe $\mathrm{z}$ eksportem na rynki międzynarodowe. W zakresie powiązań $\mathrm{z}$ profilem działalności należy zwrócić uwagę, że większość przedsiębiorstw z grupy trzeciej (produkcja metali, maszyn, urządzeń i aparatury) charakteryzuje się słabym stopniem zawansowania zmian technologicznych, co wynika z faktu największej kapitałochłonności zmian technologicznych w przypadku tego typu produkcji. 
Tabela 4. Powiązania między poziomem zaawansowania zmian technologicznych a cechami przedsiębiorstw

\begin{tabular}{|c|c|c|c|c|c|}
\hline & \multirow[t]{2}{*}{ Wyszczególnienie } & \multicolumn{4}{|c|}{$\begin{array}{l}\text { Liczba przedsiębiorstw wg poziomu } \\
\text { zaawansowania zmian technol.* }\end{array}$} \\
\hline & & $\mathrm{BD}$ & $\mathrm{D}$ & $\mathrm{N}$ & $\mathrm{BZ}$ \\
\hline \multirow[t]{5}{*}{ własność } & państwowa & & 3 & 3 & 3 \\
\hline & prywatna z KZ & 4 & 2 & & \\
\hline & prywatna NFI & & 3 & & \\
\hline & prywatna $\mathrm{z}$ inw. strat & & 1 & 1 & \\
\hline & prywatna (rozprosz. akcj.) & & 2 & & \\
\hline \multirow[t]{3}{*}{ typ wielkości } & bardzo duże & 1 & 3 & 1 & \\
\hline & duże & 3 & 8 & 2 & 3 \\
\hline & średnie & & & 1 & \\
\hline \multirow[t]{4}{*}{ funkcja } & międzynarodowa & 1 & 1 & 1 & \\
\hline & krajowa $(\mathrm{m})$ & 3 & 10 & & 1 \\
\hline & krajowa & & & 2 & 1 \\
\hline & ponadregionalna & & & 1 & 1 \\
\hline \multirow[t]{4}{*}{ położenie } & miasto bardzo duże (Kraków) & 2 & 5 & 1 & 1 \\
\hline & miasto duże & & 2 & & \\
\hline & miasto średnie & 2 & 4 & 2 & 1 \\
\hline & miasto małe & & & 1 & 1 \\
\hline \multirow{4}{*}{$\begin{array}{l}\text { profil } \\
\text { działalności } \\
\text { (wg działów } \\
\text { PKD) }\end{array}$} & $\begin{array}{l}\text { I - Prod. art. spożywczych i wyr. } \\
\text { tytoniowych (dział nr } 15 \text { i 16) }\end{array}$ & 1 & 3 & 1 & \\
\hline & $\begin{array}{l}\text { II - Prod. wyrobów chemicznych } \\
\text { i gumowych (nr 24, 29) }\end{array}$ & 2 & 3 & & \\
\hline & $\begin{array}{l}\text { III - Prod. metali, maszyn, urządzeń } \\
\text { i aparatury (nr 27, 28, 29, 31, 32) }\end{array}$ & & 2 & 3 & 3 \\
\hline & $\begin{array}{l}\text { IV - Prod. pozostała: odzieży, wy- } \\
\text { robów z surowców niemetalicznych } \\
\text { i drewna }(\mathrm{nr} 18,20,26)\end{array}$ & 1 & 3 & & \\
\hline \multicolumn{2}{|l|}{ Ogółem } & 4 & 11 & 4 & 3 \\
\hline
\end{tabular}

* BD - bardzo duże zmiany, D - duże zmiany, $\mathrm{N}$ - niewielkie zmiany, BZ - brak zmian technologicznych Źródło: opracowanie własne

Warto postawić pytanie, czy przeprowadzony proces restrukturyzacji technologicznej badanych przedsiębiorstw pozwala na zajęcie pozycji konkurencyjnej w otoczeniu międzynarodowym, w szczególności w otoczeniu europejskim, po wejściu Polski do Unii Europejskiej. Włączenie Polski do struktur europejskich oznacza dla przedsiębiorstw przemysłowych przyjęcie unijnych reguł gospodarowania, w tym przede wszystkim uczestnictwa we wspólnym wewnętrznym rynku zapewniającym swobodny przepływ kapitału, usług, towarów i osób. Do podstawowej szansy związanej z integracją europejską powszechnie zalicza się uczestnictwo w jednolitym rynku wewnętrznym UE, co oznacza rozszerzony dostęp do niego dla polskich producentów. Należy jednak zwrócić uwagę na niski poziom konkurencyjności produkcji badanych przedsiębiorstw, ze względu na brak modernizacji bądź wymiany linii technologicznych. Oznacza to tym samym problemy rozwoju eksportu do krajów UE tych przedsiębiorstw, które nie wprowadziły zmian technologicznych lub zmiany te były niewielkie. Do takich zagrożonych przedsiębiorstw należą nie tylko pozostające w procesie likwidacji, jak KZE „Telpod” czy ZM „Nisko”, ale także np. Huta Tadeusza Sendzimira. Pełne otwarcie się na wspólny rynek i tym samym większa presja konkurencyjna ze 
strony zagranicznych przedsiębiorstw powoduje, że szanse, jakie stwarza integracja z UE, wykorzystają zapewne tylko najsilniejsze przedsiębiorstwa, które przeszły pomyślnie pierwszy etap restrukturyzacji i wprowadziły duże zmiany technologiczne produkcji. Do takich zaliczyć można m.in. Dębicę, Plivę, Wawel, Vistulę (w zakresie przerobu uszlachetniającego). Dodatkowym wyzwaniem dla przedsiębiorstw jest także konieczność przyjęcia szeregu unijnych regulacji, wśród których - oprócz wymogów jakościowych - ważne znaczenie z punktu widzenia analizy opłacalności produkcji mają przepisy związane z ochroną środowiska. Dostosowanie się do unijnych wymogów w tym zakresie wymaga jednak bardzo często głębokich, kapitałochłonnych zmian technologicznych. W krótkim okresie może więc zaowocować wzrostem kosztów produkcji (ze względu na konieczne wysokie nakłady kapitałowe) i tym samym uczynić produkty niekonkurencyjnymi (por. Sadowski 2003). W większości badanych przedsiębiorstw trwają jednak prace przygotowawcze w zakresie dostosowania się do norm UE, co pozwoli im na podjęcie walki konkurencyjnej w otoczeniu międzynarodowym.

\section{Literatura}

Nalepka A., 1997, Istota, zakres i metodyka restrukturyzacji przedsiębiorstwa, [w:] Restrukturyzacja a konkurencyjność przedsiębiorstw, red. R. Borowiecki, Materiały z konferencji, AE w Krakowie, Kraków

Nalepka A., 1998, Zarys problematyki restrukturyzacji przedsiębiorstw, Antykwa, Kraków

Parysek J.J., 1992a, Polski przemyst a nowe warunki spoteczno-ustrojowe, [w:] Studia geograficzne przemian spoteczno-gospodarczych, red. Z. Chojnicki, Biuletyn KPZK PAN, z. 159, s. 75-88

Parysek J.J., 1992b, Dobrodziejstwo inwentarza czyli jak zrestrukturyzować przemyst Polski, [w:] Geografia przemystu $w$ warunkach nowego systemu gospodarowania - problemy badawcze $i$ odzwierciedlenie ich w kształceniu nauczycieli, red. Z. Zioło, Komisja Geografii Przemysłu PTG, Kraków-Warszawa, s. 28-45

Pasieczny J., 1997, Restrukturyzacja - wczoraj, dziś i jutro, [w:] Restrukturyzacja a konkurencyjność przedsiębiorstw, red. R. Borowiecki, AE w Krakowie, Kraków

Pełka B., 1994, Restrukturyzacja przedsiębiorstwa przemystowego, cz. I i II, Instytut Organizacji i Zarządzania w Przemyśle „Orgmasz”, Warszawa

Rachwał T., 2000a, Zmiany funkcjonowania Zaktadów Przemystu Cukierniczego „San” S.A. w Jarostawiu pod wptywem inwestycji zagranicznych, [w:] Działalność człowieka i jego środowisko, red. Z. Zioło, Wyd. Nauk. AP, Kraków, s. 323-336

Rachwał T., 2000b, Wptyw inwestycji zagranicznych na zmiany w funkcjonowaniu Huty Szkła Jarostaw S.A. w procesie transformacji gospodarczej, Rocznik Naukowo-Dydaktyczny AP w Krakowie, z. 209, Prace Geograficzne XVIII, red. Z. Zioło, s. 63-72

Rachwał T., 2001a, Proces restrukturyzacji Zaktadów Mięsnych „Nisko” S.A. jako potencjalny czynnik aktywizacji rolniczej bazy surowcowej pótnocnej czesści województwa podkarpackiego, [w:] Problemy przemian struktur przemystowych $w$ procesie wdrażania regut gospodarki rynkowej, red. Z. Zioło. Prace Komisji Geografii Przemysłu PTG nr 3, Warszawa-Kraków-Rzeszów, s. 181-189

Rachwał T., 2001b, Funkcjonowanie Krakowskich Zakładów Elektronicznych „TELPOD” w świetle przemian $w$ polskim przemyśle elektronicznym, [w:] Problemy przemian struktur przemystowych w procesie wdrażania reguł gospodarki rynkowej, red. Z. Zioło. Prace Komisji Geografii Przemysłu PTG nr 3, Warszawa-Kraków-Rzeszów, s. 167-180

Sadowski Z., 2003, Kierunki modernizacji strukturalnej polskiego przemystu, [w:] Gospodarka Polski przed wejściem do Unii Europejskiej, red. J. Lipiński, A.Sławiński, PWE, Warszawa, s. 13-22

Sapijaszka Z., 1997, Restrukturyzacja przedsiębiorstwa. Szanse i ograniczenia, WN PWN, Warszawa

Stryjakiewicz T., 1999, Adaptacja przestrzenna przemystu $w$ Polsce $w$ warunkach transformacji, WN UAM, Poznań 